Hydrol. Earth Syst. Sci. Discuss., 4, 4297-4323, 2007 www.hydrol-earth-syst-sci-discuss.net/4/4297/2007/ (C) Author(s) 2007. This work is licensed under a Creative Commons License.

Papers published in Hydrology and Earth System Sciences Discussions are under open-access review for the journal Hydrology and Earth System Sciences

\title{
Water management in the Senegal River Delta: a continuing uncertainty
}

\author{
M. Mietton ${ }^{1}$, D. Dumas ${ }^{2}$, O. Hamerlynck ${ }^{3}$, A. Kane ${ }^{4}$, A. Coly ${ }^{5}$, S. Duvail ${ }^{6}$, \\ F. Pesneaud ${ }^{7}$, and M. L. O. Baba ${ }^{8}$
}

${ }^{1}$ Centre de Recherche en Géographie et Aménagement, UMR 5600, Université J. Moulin Lyon 3, 18 rue Chevreul, 69362 Lyon Cedex 07, France

${ }^{2}$ Institut de Géographie Alpine, Université J. Fourier Grenoble 1, 14bis, avenue Marie-Reynoard, 38100 Grenoble, France

${ }^{3}$ Centre for Ecology and Hydrology, Wallingford, Crowmarsh Gifford, Oxfordshire, UK

${ }^{4}$ Université Cheik Anta Diop, Département de Géographie, BP 5005 Dakar Fann, Sénégal

${ }^{5}$ Université Gaston Berger, Section de Géographie, Saint-Louis, Sénégal

${ }^{6}$ IRD, UR 169, IFRA (Inst. Francais de Recherche en Afrique), PO. Box 58480, Nairobi,Kenya

${ }^{7}$ Université Louis Pasteur, Faculté de Géographie, 3 rue de l'Argonne, 67083 Strasbourg

Cedex, France

${ }^{8}$ UICN Mauritanie, BP 41167 Nouakchott

Received: 13 November 2007 - Accepted: 14 November 2007 - Published: 30 November 2007

Correspondence to: D. Dumas (dominique.dumas@ujf-grenoble.fr)

HESSD

4, 4297-4323, 2007

Water management in the Senegal River

Delta

M. Mietton et al.

Title Page

Abstract

Introduction

Conclusions

References

Tables

Figures

14

$\rightarrow$

4

Back

Close

Full Screen / Esc

Printer-friendly Version

Interactive Discussion 


\section{Abstract}

Water management is the driving force behind the productivity of the ecosystems of the Senegal River Estuary and floodplains. It is dependent on human decision-making, but has been separated from the River's flooding since the building of the Diama Dam. The

5 current objectives of the Office de Mise en Valeur du fleuve Sénégal (OMVS: Senegal River Development Agency) are mainly turned towards the development of irrigated agriculture on the former floodplains and since 2002 the production of hydroelectric power at Manantali. In October 2003, a four-metre-wide runoff canal, which quickly widened into a breach several hundred metres across, was dug in the Barbary Spit area

to protect the city of Saint-Louis from heavy flooding. The hydraulic quality of the area downstream from the dam has improved to the extent that there is no longer any flooding there, but as the management of the dams concerns only the section of the river between Manantali and Diama, a certain amount of flood risk probably still persists. The intrusion of seawater into the estuary is also threatening ecosystems and fresh growing in the Gandiolais district. When added to the tentative efforts to coordinate the management of the two dams, with no management objective downstream from Diama, such permanent modifications impose serious constraints on the managers and residents of the lower delta. This paper presents an overview of the constraints and uncertainties at different levels and scales. This wholly human-wrought environment can be considered as a learning experience, where a large number of variables need to be monitored closely and an ongoing process of participatory analysis should be backed up by multidisciplinary research.

\section{Introduction}

25 Uncertainty can be defined as the state of that which is not fixed or determined, and by extrapolation as misgiving about an unknown future. Often accompanied by anxiety,
HESSD

4, 4297-4323, 2007

Water management in the Senegal River

Delta

M. Mietton et al.

Title Page

Abstract

Introduction

Conclusions

Tables

References

Figures

14

4

Back

Close
Printer-friendly Version

Interactive Discussion 
such misgiving is an inherent factor in the lives of Sahel dwellers, due to the year-toyear variations in rainfall which regulate agricultural and pastoral resources. As such, it has shaped strategies of defence and adaptation, patiently assembled throughout these societies' histories to enable them to attenuate climatic risks. Such uncertainty 5 is linked to successive parameters (e.g. the date at which useful rain begins to fall, rainless periods in the middle of the rainy season, and the latter's length) and is part of a definite, seasonal timeframe. Uncertainty is thus, as it were, "normal", expected and understood. Also expected but less well understood is the uncertainty experienced by all those who depend on a river for their water supply, the production of which is 10 a result of climatic conditions in some far-off, little- or unknown upstream area. In addition, the same climatic uncertainty may come with greater or lesser constraints: a severe drought happening several years in a row becomes unendurable and today no longer seems acceptable. Our technological societies are therefore tempted to cure such recurrent afflictions with remedies such as dams. This was the case in the 15 Senegal River basin with the building of the Diama and Manantali dams in 1985 and 1988 respectively, after 20 long years of drought (see Fig. 1).

New "anomalies", however, seem to be connected with continuing trial-and-error in the two dams' management as well as with negative impacts for which no measures of compensation or attenuation were planned for, financially or otherwise. Finally, in October 2003, when the city of St-Louis was flooded, an artificial canal was dug across the Barbary Spit; this had positive effects at the time, but massive penetration of the lower estuary by seawater is now proving disastrous (see Fig. 1). This is how uncertainties change, and humans no longer quite seem the masters of their own techniques and solutions. Even scientists have few certainties, with question marks hanging over pos-

sible threshold effects, or the response times of this or that parameter. The continual adaptations the stakeholders living in the immediate vicinity of the river are required to make result in lassitude, disillusion or at the very least economic difficulties arising from new production methods.

Effects in man action, can be here divided into two kinds: measured ones resulting
HESSD

4, 4297-4323, 2007

Water management in the Senegal River Delta

M. Mietton et al.

Title Page

Abstract

Conclusions

Tables

Figures

14

$\rightarrow 1$

4

Back

Close

Full Screen / Esc

Printer-friendly Version

Interactive Discussion 
evidently from dam building and predictable ones potentially deriving from spit breaching. The paper deals in succession with them.

\section{Dams: new ressources, new constraints}

There is no question here of saying that the situation in pre-dam period was ideal. The 5 natural environment seriously circumscribed sustainable development: there could be huge variations in climatic conditions, with great disparities in rainfall, as well as in the size, height and duration of floods; soils were exposed to increasing salinity as the saltwater table rose up into the delta and the saline undercurrent flows upriver; finally, water management was made difficult by the flat landscapes and the need to build complex, costly infrastructures for flood protection, irrigation and drainage.

The situation became definitely more worrying during the 1970s and 1980s, however, when the whole of West Africa was stricken by drought, as shown by the graphs of tenyear mean isohyets (Puech, 1983; Albergel et al., 1984; Venema et al., 1997); isohyet $900 \mathrm{~mm}$ has moved southwards by nearly two degrees along certain meridians. In 15 the Sudanese Sahel, the Senegal River flow was significantly depleted, as its annual mean at Bakel dropped by an average of $75 \%$ between 1970 and 1990 , and by $50 \%$ just during the 1980s (Mahé and Olivry, 1995). Governments' growing misgivings, as well as increasing international awareness explain why a tripartite authority, the Office de Mise en Valeur du fleuve Sénégal (OMVS: Senegal River Development Agency), 20 was set up in March 1972 with the trans-national political purpose of overcoming the usual local preoccupations and disagreements.

\subsection{Ambitious aims, mixed results}

The OMVS's major objective is to improve the three member countries food supply by creating 375000 ha (hectares) of irrigated land: 240000 ha in Senegal, 126000 ha in

Mauritania and 9000 ha in Mali. The annual yield of these hydro-agricultural schemes
HESSD

4, 4297-4323, 2007

Water management in the Senegal River

Delta

M. Mietton et al.

Title Page

Abstract

Introduction

Conclusions

Tables

References

Figures

14

- I

4

Back

Close

Full Screen / Esc

Printer-friendly Version

Interactive Discussion 
is forecast to be $12 \mathrm{t}$ per hectare, in addition to a farming-sector growth rate of $10 \%$ per annum. Two dams were built in order to achieve these aims. Work started on the downriver one, Diama, in 1981 and finished in 1985. The dam's purpose was to stop the saline seawater intrusion flowing up the Senegal River Valley. The work on the 5 upriver dam, Manantali, was begun in 1982 and completed in 1988. It has a holding capacity of $12 \mathrm{~km}^{3}$, and is mainly designed to supply irrigated farmland with water and the three fast-growing capitals with electricity. The dam's hydroelectric power station has a generating capacity of $800 \mathrm{GwH}$ a yr. In as far as Manantali Dam enables the river's water levels to be kept reasonably high during the dry season, the authorities 10 have also decided to develop year-round boat traffic on the river, running from SaintLouis up to Kayes in Mali. This transformation of the river valley, thought up in the 1970s and carried out in the late 1980s, implicitly presupposes the successful change from a seasonal economy of hunting-gathering and extensive agriculture to one consisting of intensive, permanent agriculture whose profitability was overestimated from the outset 15 (Engelhard, 1991; Duvail, 2001).

The outcome can first be assessed macro-economically by comparing results with initial objectives in three important domains: irrigation, hydroelectric power production and navigation.

- Irrigated agriculture, currently covering 125000 ha of large perimeters, is develop20 ing much less quickly than expected. None of the areas equipped for irrigation is anywhere near being completely cultivated. On individual plots, yields have plummeted to an average of $4 \mathrm{t}$ per hectare after three years' cultivation (Ceuppens et al., 1999).

- Objectives for hydroelectric power production were reached by the end of 2002. All three capitals now have reliable power supplies, and for the countries concerned the benefits of this are far from insignificant. For anyone who knew Bamako in the 1980s, for example, current living and production conditions have obviously improved. Power production, whose economic viability level is estimated at $800 \mathrm{GwH} / \mathrm{yr}$, is nevertheless subject to new constraints linked to efforts to reconcile more-or-less contradictory objectives. Manantali's stock of water is not only used to generate hydroelectric

HESSD

4, 4297-4323, 2007

Water management in the Senegal River Delta

M. Mietton et al.

Title Page

Abstract

Introduction

Conclusions

Tables

References

Figures

14

$\rightarrow 1$

4

Back

Close

Printer-friendly Version

Interactive Discussion

EGU 
power but also to compensate for inadequate flooding or low river flow, and allows some post-flood crop-growing and large irrigated crop-growing (Bader et al., 2003). The advantages of extensive post-flood agriculture, whose yields are low (1t/ha/yr), has clearly been under-estimated. Although it was supposed to have been kept up on

5 a purely temporary basis, it has turned out to be essential for the inhabitants of the lower-middle valley. In addition, the water released in vast quantities from Manantali to boost natural rises in river levels cannot all be put through the turbines, and is lost for potential irrigation purposes as well.

- There has been no real improvement in the river's navigability as far as Mali. Could 10 it have been otherwise? Huge financial investments would have been necessary to upgrade the riverbed dimensions, and this was unlikely since trade between Mali and the ocean does not transit by Saint-Louis, where there are no proper port facilities. The recent stopovers in Saint-Louis of the well-known liner Bou-el-Mogdad, transformed for taking tourists on cruises to the towns of Richard Toll and Podor, is beside the point and will do nothing to turn such wishful thinking into concrete action.

\subsection{Other unexpectedly serious impacts}

Over and above the mixed results just described, there has also been the emergence of new difficulties affecting the environment, the socio-economic situation and the population's health, often acting in interrelated ways or by "impact synergy" (Blanchon, 20 2003).

- One of the main difficulties, stressed by all the stakeholders, has been the increase in the number of invader aquatic species, linked to the permanent presence of fresh water upriver from Diama. Although the proliferation of plants such as Salvinia molesta and Pistia stratiotes seems to be under control today, others like Typha australis
HESSD

4, 4297-4323, 2007

Water management in the Senegal River

Delta

M. Mietton et al.

Title Page

Abstract

Introduction

Conclusions

Tables

References

Figures

14

$\rightarrow$

4

Back

Close

Printer-friendly Version

Interactive Discussion and financial efforts which in the end come to little, given the uncontrollable dissemination of airborne seeds. This type of infestation has seriously impaired access to, 
and movement around, waterways, especially for fishermen. Water flow in canals and tributaries has become sluggish and sedimentation occurs (Philippe et al., 1998). It resulted in sheltering and nesting possibilities for harmful animal species, especially the grain-eating bird Quelea quelea. In the basins of the Mauritanian bank, doing away 5 with the artificial dry-season flood has even been envisaged - despite the fact that it is the most telling example of complete human control over the river's water resources - in order to stop the spread of Typha australis. The economic and financial feasibility of developing a new industry to promote the latter's use (for fuel, methane production, wickerwork, building material and animal fodder) has yet to be established. In addition 10 to creating a large number of jobs, it would most likely be the best way to control the species' spread (Theuerkorn et al., 2005).

- The modification of the quality and quantity of hydrological conditions (permanence of water lines and enlargement of water-covered areas) may have contributed to the emergence of new health problems. The relationship has not been proven, however, and must be considered with caution. "The relationship between the presence of intermediate hosts or vectors and a specific disease (e.g. bilharziosis, malaria) is neither immediate nor inevitable. In the same way, there is no necessary link between irrigated areas and the appearance of intermediate hosts and vectors." (P. Handschumacher, in Philippe et al., 1998: p. 398, translated from French). Handschumacher particularly shows how the epidemic of intestinal bilharziosis at the town of Richard Toll, which is in total geographical contrast with the usual distribution in West Africa of Schistosoma mansoni, was able to gain hold in a new ecological environment with permanent fresh water. The stabilising of the levels of Lake Guiers and the main canals supplying the nearby sugarcane fields may have resulted in the steadying of temperatures. This in 25 itself would not have been enough, however: the transmission cycle can only be completed by intermediate hosts being infested and this can only occur through diseased people arriving from a zone where the disease is endemic. Richard Toll, as it happens, is a plantation town which attracts a large labour force, some of it from the south of the country, outside the surrounding region. The Diama anti-salt dam cannot therefore
HESSD

4, 4297-4323, 2007

\section{Water management in the Senegal River Delta}

M. Mietton et al.

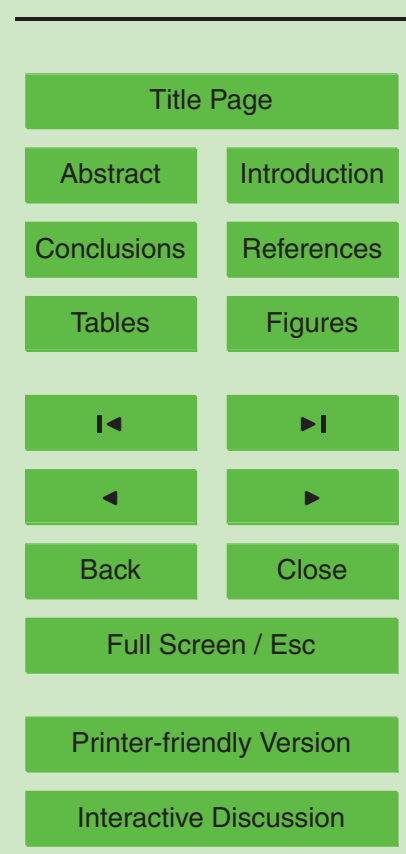

EGU 
be held directly responsible for the spread of the disease. There has been an indirect influence, however, since the increased availability of water for irrigation has favoured the extension of sugar-producing areas and the expansion of the work force.

- It is probably in the socio-economic domain that the major spatial upheavals have 5 occurred and concern been the most persistent. Like all dams, Diama constitutes a frontier. In this case, however, where an anti-salt barrier has been built close to the ocean, the dividing line between the two hydrographical sectors is more marked than in ordinary dams, the upriver and downriver areas being highly distinct in water quality and flow dynamics (Barusseau et al., 1998). Traditional, small-scale fishing, whose 10 annual production is estimated to have dropped from 30000 to $8000 \mathrm{t}$, has clearly borne the brunt of the rupture (Bousso, 1997). The decline in the quality and quantity of fish stocks is linked to alterations in the hydrodynamic characteristics of the estuary and in particular to a reduction in the regular flushing mechanism. A fish corridor at Diama would be unlikely to limit this disruption.

15 As things stand, and notwithstanding some efforts, development and its sustainability seem no surer than they were 10 years ago during our work on the CNRS (French National Research Institute's) project on "the transformation of hydrosystems downstream from large dams (the Senegal River Delta)". Soils remain fragile, due to salinisation processes. It is well known that protection against salinisation requires a

well-designed drainage network with two functions: on the one hand to ensure that the saltwater table stays deep enough (at least $70 \mathrm{~cm}$ ) in order to prevent its coming into contact with the layer of water covering the paddy fields; on the other hand, to drain this water layer completely from time to time to prevent plots of land acting as basins concentrating the salts dissolved in the irrigation water. Water problems concern both quantity and quality, including waste water full of pesticides and weed-killers which no one knows how or where to get rid of (Mietton et al., 1991; Humbert et al., 1995). In spite of the fact that impact studies recommended building a canal to evacuate waste water, it was never budgeted for and at the time of writing remains unfinished. In practice, drainage is all too often badly done, poorly maintained or simply inexistent,
HESSD

4, 4297-4323, 2007

Water management in the Senegal River Delta

M. Mietton et al.

Title Page

Abstract

Introduction

Conclusions

Tables

References

Figures

14

$\rightarrow$

4

Back

Close

Full Screen / Esc

Printer-friendly Version

Interactive Discussion 
resulting in the increasing salinisation of areas which then have to be abandoned. The Senegalese "model" thus resembles a sort of "itinerant rice cultivation", as Pesneaud (1996), combining two generally contradictory terms, so well put it. The chronic instability of Senegalese rice-growing agriculture seems to be due to several factors, the 5 main one being hydraulic. Drainage techniques are poorly mastered, and it has proven difficult to get rice fields perfectly level. The latter are moreover too large for the insufficiently mechanised farming methods in use. Extensive restoration work in these areas is undoubtedly necessary in the short term, which would obviously prove costly for farmers' organisations. All in all rice-growing is proving to have very high social and ecological costs. The quality of the people involved is not in question, even if it is true that their "water-management culture" is not yet in full maturity. The choice to create ex nihilo a rice-growing sector dependent on irrigation was national, international and macro-economic, reinforced by the possibility of developing a magnificent amphibian area, hitherto sparsely populated, with water at very low cost. Currently the situation 15 is deadlocked in many ways: environmentally of course, but financially and institutionally as well. Faced with so many obstacles, the chosen model's future seems open to question (Pesneaud, 1996).

\subsection{The limits of hydraulic management}

The hydraulic management of Manantali Dam was seen above to have become subject 20 question might not have been studied more thoroughly before the dam was built. If they had been, its size could have been adapted so as to meet a variety of needs better.

Moreover, there are several other factors to note:

- It should be remembered that not all of the drainage basin, downriver from Bakel, 25 is regulated by Manantali Dam; the inflows from the Falémé and Baoulé Rivers, as well as the severe Sahelian floods (Térékollé-Kolimbinné-Lac Magui) are outside its control. Downriver, Diama can just be subjected to unrestrained flooding, which can take around $20 \mathrm{~d}$ to arrive from Bakel. Coordinated management of the two dams is 4305
HESSD

4, 4297-4323, 2007

Water management in the Senegal River Delta

M. Mietton et al.

Title Page

Abstract Introduction

Conclusions

Tables References Figures

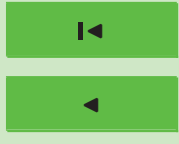
$\rightarrow$

Back

Close

Full Screen / Esc

Printer-friendly Version

Interactive Discussion 
also made more difficult by the fact that although Manantali is now expected to be holding as much water as possible at the end of summer, it can no longer limit possible floods caused by the passage of showery fronts at the end of the rainy season.

- Diama's functioning is subject to both its own mechanical stability and to its use as

5 a reservoir, something which had not originally been planned. With regard to the first point, up to recently dissipation energy had been strictly limited to $1000 \mathrm{~m}^{4} / \mathrm{s}\left(1000 \mathrm{~m}^{3} / \mathrm{s}\right.$ under a one-metre drop) by the regulations governing the running of the dam (Coyne and Bellier, SOGREAH, 1987). However, a recent engineering study redid the calculations following a rise in the tidal range downriver from the dam, and concluded that 10 problems of dissipation energy were no longer of the same order, since, surprising as it may seem, it could quite simply be multiplied by 15 ! Whatever the figures, the dam's resistance was a real-life subject of concern in 2004 and 2005 when water had to be diverted from the river in Keur Macène district, upriver from Diama, over the right bank towards Aftout es Sahel.

15 - Originally designed as a barrier against salt, Diama has little by little been assigned an extra function as a reservoir: the average water level of $1.50 \mathrm{~m}$ in 1992 rose to $1.75 \mathrm{~m}$ in 1995, $1.90 \mathrm{~m}$ in 1997, $2.0 \mathrm{~m}$ in 1999 and has been $2.10 \mathrm{~m}$ since 2002. This is another instance where hydraulic engineers are being asked to respond to the insistence of the farming and agro-industrial sectors by maintaining high water levels in order to ensure the gravitational irrigation of farmland and thus economize on fuel oil (Duvail, 2001).

- Conflicting objectives linked to the benefits of artificial flooding give rise to other types of problem, since the interest of human-made floods inevitably causes conflicts between potential users. Natural floods used to be adapted to, whereas artificial ones are decided on; but for whose benefit? User conflicts (Duvail, 2001; Duvail et al., 2001; Duvail et al., 2003; Hamerlynck et al., 2005) mainly occur in the Lower Mauritanian Delta, where the rice-growing "model" takes up only part of the land, and traditional activities of fishing, breeding and gathering take place within a patchwork of landscapes alongside protected ecosystems such as Diawling National Park (DNP) with their avian

HESSD

4, 4297-4323, 2007

\section{Water management in the Senegal River Delta}

M. Mietton et al.

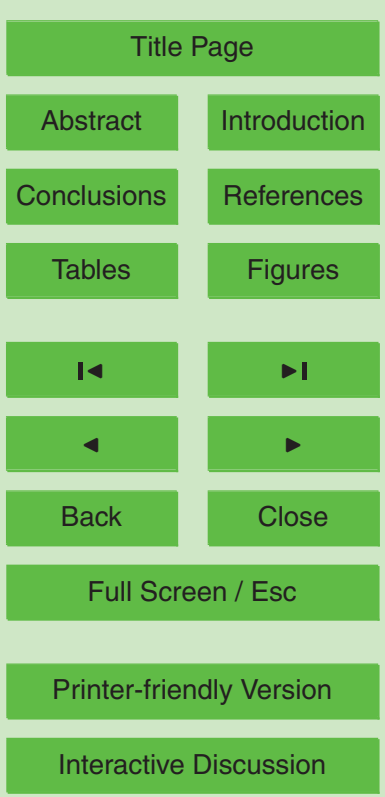

EGU 
wildlife.

Over the last two decades, the various stakeholders have had to adapt, first to the HESSD delayed building of an embankment along the right bank and then to frequent, unpredictable modifications in the way Diama and Manantali Dams are run. More recently, 5 between 2002 and 2005, a commonly-agreed calendar was drawn up, but then not respected. Everybody should have been satisfied - including the managers of DNP, as more regular releases of water from Diama would eliminate risk of excessive salinisation of the Lower Mauritanian Estuary (N'Tiallakh) - with the important exception of pastoral farmers, who rely on a short off-season flood to supply their herds with water, 10 particularly welcome at the end of the dry season. If the management plan is not respected it is likely to lead to lasting disgruntlement among these breeders. It may well explain their absence from talks with the DNP and IUCN in February 2006.

Contradictory objectives and accelerated, imperfect adaptations: the time of uncertainty is not ended. Increasing water management skills have nevertheless begun to bear fruit, on the Mauritanian side of the river at least, as regards improvements in biodiversity and economic production. Unfortunately, in late 2003 a new incident upset things: the artificial breaching of Barbary Spit.

\section{Barbary spit: new uncertainties brought about by the breach}

\subsection{The history and evolution of the breach}

20 The level of the Senegal River rose steadily throughout September 2003. A maximum flow of $3505 \mathrm{~m}^{3} / \mathrm{s}$ was recorded at Bakel on the 23rd. At St-Louis a maximum height of $1.42 \mathrm{~m}$ above the reference level was reached on 28 September, and remained at $1.41 \mathrm{~m}$ over the next few days. Faced with the discontentment of the local population and possibly subjected to pressure by the authorities, managers decided to open a breach across the narrow coastal spit, thereby bringing the river mouth closer to the town ( $7 \mathrm{~km}$ south of Faidherbe Bridge as against about 30 previously) and bringing

\section{Water management in the Senegal River \\ Delta}

M. Mietton et al.

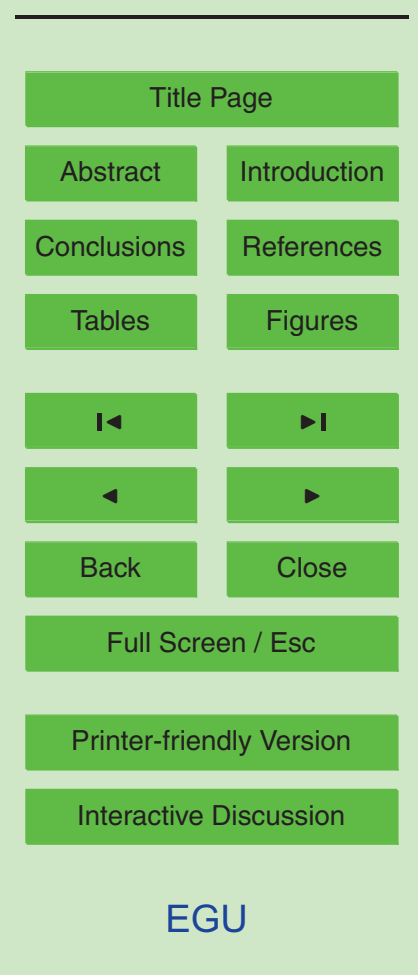


about a reduction in hydraulic load. It should be noted that this flood-protection measure had been suggested, along with others, in a UNEP report as far back as October 2002 , but ought to have been accompanied by additional measures such as the construction of protective groynes next to the breach, something which was not done in 5 October 2003. During the night of 3 October, a 4 m-wide channel was dug (see Fig. 2); the height of the river as measured at the bridge dropped considerably over the following $48 \mathrm{~h}$ and by nearly a metre in $10 \mathrm{~d}$. The second high point at Diama on 29 October 2003 was not even visible on water gauges at St-Louis.

Meanwhile, however, the breach widened rapidly (Kane et al., 2003), reaching $400 \mathrm{~m}$ 10 in a few weeks, and continued opening up at a relatively steady rate of around a metre a day. On April 2006, the beach was $1.4 \mathrm{~km}$ wide (see Figs. 3 and 4). This continued widening is mainly due to active erosion of the southern part of spit by a NW or NNW ocean swell (Kane, 1997). The northern bank of the breach is still relatively mobile: sandy deposits accumulate in places and move it slightly southward.

\subsection{Flood risks in Saint-Louis}

The 2003 flood can be interpreted in different ways. Here are several observations:

- The intensity of a flood is not simply related to the maximum height reached by the river but also to the length of time the banks are overflowed, the local rainfall, the building of dykes. After 1994, the construction of an embankment along the eastern edge of the Sor district modified the relationship between the height of the river and the extent of flooding. The embankment has then undeniably worked to a certain extent, since the floods in 1997, 1998 and 1999 were not as severe as in 1994 (Laperrière, Lucchetta, 2003), despite higher water levels on the river. If the flood alert threshhold for St-Louis is taken to be around $1.20 \mathrm{~m}$ (UNEP, 2002), this needs to be modulated according to the context of each incident.

- It has to be conceded that the 2003 flood, although a major one, was nothing out of the ordinary (see Fig. 5). The maximum water level recorded at Saint-Louis in 2003 was $142 \mathrm{~cm}$, considerably lower than in $1999(164.5 \mathrm{~cm})$ or $1950(179 \mathrm{~cm})$.

\section{8}

HESSD

4, 4297-4323, 2007

Water management in the Senegal River

Delta

M. Mietton et al.

Title Page

Abstract

Introduction

Conclusions

Tables

References

Figures

14

$\rightarrow$

4

Back

Close

Full Screen / Esc

Printer-friendly Version

Interactive Discussion 
- There have been recurrent floods in Saint-Louis from the mid-1990s onwards: $1994(126.5 \mathrm{~cm}), 1995(120.5 \mathrm{~cm}), 1997(128.5 \mathrm{~cm})$. This contrasts with the preceding 20 years, when there had been none since 1974 .

It can therefore be wondered whether it is not so much hydrological conditions which

5 have changed as St Louis's vulnerability; housing has increased following demographic growth, particularly in the most low-lying districts. This may have been due to carelessness during the floodless years, aggravated by the authorities failure to put a stop to it. The building of the dams may even have led it to be thought, more or less consciously, that there was no longer much danger of flooding.

10 - In the two years following the 2003 breach, the river's level at St-Louis did not exceed $50 \mathrm{~cm}$ (see Fig. 5), despite outflow volumes from Diama dam similar to those in the years preceding 2003. However, the diversion of water towards Aftout es Sahel in 2004 and 2005 needs to be taken into account, which means that the question arises of whether Saint-Louis's flood risk has been permanently eliminated. The radical change 15 in the slope of the river's surface suggests that the answer is affirmative. Nevertheless, the coordinated management of the two dams, however complex it may be in the Manantali-Diama stretch, must enhance safety by taking also into account the downriver section between Diama and the new river mouth, in order to reduce the amount of water which needs to be released at times of high water. Could this have been done in September 2003? Even if only Diama is considered, it seems unlikely (see Fig. 6). During the flood episode in question, water was released at rates of over $1500 \mathrm{~m}^{3} / \mathrm{s}$ from 22 August, building to 1600 to $1700 \mathrm{~m}^{3} / \mathrm{s}$ in the first fortnight of September, and reaching $1800 \mathrm{~m}^{3} / \mathrm{s}$ on 20 September, when the city was already flooded. Surprising as it may seem, flow measurements at Bakel show that the rate of runoff was continu25 ously over $2000 \mathrm{~m}^{3} / \mathrm{s}$ after the initial flow of $3680 \mathrm{~m}^{3} / \mathrm{s}$ on 10 August. Thus flow did not diminish at Diama and even reached $2000 \mathrm{~m}^{3} / \mathrm{s}$ in late September, while a second high point of $3505 \mathrm{~m}^{3} / \mathrm{s}$ was announced at Bakel for 23 September. The only favourable circumstance was that the Diama dam was low on water, at around $1.50 \mathrm{~m}$ (see Fig. 6). This was not enough to absorb the flood, however, the dam having anyway a strictly

HESSD

4, 4297-4323, 2007

Water management in the Senegal River Delta

M. Mietton et al.

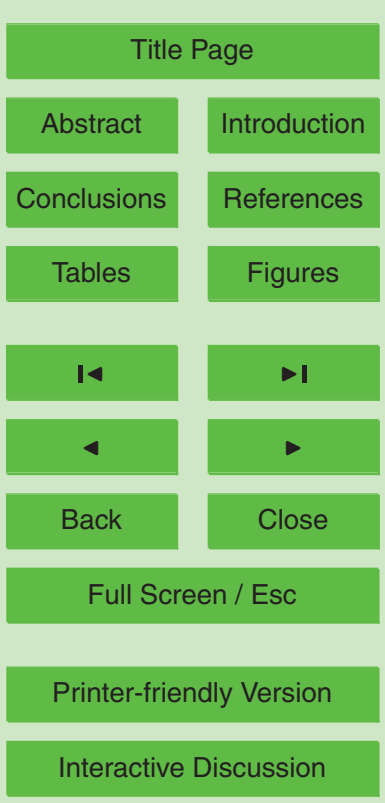

EGU 
limited capacity of absorbing any flood.

It consequently seems necessary to calculate hydraulic models of the flow characteristics of the Senegal River with the combined management of the two dams, including safety concerns downstream from Diama. A model of the sector downstream from 5 Diama was made in 2002 (UNEP, 2002). It is essential to reactivate this procedure, and take the new river mouth and its visible and undersea morphological evolution into account. The 2003 flood is likely to have been due to the partial blocking of the old river mouth, which had been regularly dredged up to the 1960s, and thus by flow being impeded downstream. This modelling should also be combined with a digital landscape 10 model of the flood plain, although the latter has yet to be made. This would enable both quantitative (floods) and qualitative (salinity) aspects to be better understood.

\subsection{The only certainty: increased tidal range}

An increase in tidal range throughout the estuary has been the clearest effect of the changes in the river mouth, and the least open to question, since it happened immedi5 ately. Modifications in semi-diurnal tide patterns can be seen in a number of ways (see Fig. 7).

First, the daily maximum tidal range, as measured at the downstream foot of Diama, has been multiplied by three, going from a 2001-2002 average of $0.30 \mathrm{~m}$ to an average of $0.93 \mathrm{~m}$ in 2004-2005. Next, since 2004 it has become a year-long phenomenon, 20 even during the summer high-water period when it did not previously occur (see Fig. 7). Finally, the amplitude of the 14-d spring-tide cycle has also been reinforced. At Diama, the amplitude between spring-tide and its accompanying neap-tide has more than doubled. Following a complex pattern of interacting impacts, the increase in tidal range, with a drop of $30 \mathrm{~cm}$ and a rise of the same amplitude, can have various effects over 25 response times of differing lengths. From a geotechnical standpoint, such a tidal range can have undermining and/or gouging effects from which the wharves of Saint-Louis, the piers of Faidherbe Bridge, and even the foundations of Diama Dam may not be exempt. It should be recalled that it was in this context that a new study of the dissi-

\section{HESSD}

4, 4297-4323, 2007

Water management in the Senegal River Delta

M. Mietton et al.

Title Page

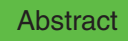

Introduction

Conclusions

Tables

References

Figures

14

$\rightarrow$

4

Back

Close

Full Screen / Esc

Printer-friendly Version

Interactive Discussion 
pation energy downstream from Diama was ordered. The economic effects have not been positive either, according to surveyed fishermen on the banks of the N'Tiallakh, because the water rises and falls more quickly. However, from an ecological point of view, at least as far as the mangrove is concerned, a regeneration is under way in a 5 number of places (e.g. Bango near Saint-Louis, the northern part of the Gandiolais district, the Bell-N'Tiallakh confluence), due to the rise of water to levels not seen since the Diama Dam began operating and the natural annual flooding stopped occurring. It also supposes that the water is brackish rather than very salty.

\subsection{Main incertitude: salinity evolution}

10 Salinity currently appears to be evolving under the influence of two opposing factors: on the one hand, a more hydrodynamically efficient intrusion of sea water as far as Diama, on the other, the discharging of fresh water at Diama, which since late 2002 has never gone below $100-200 \mathrm{~m}^{3} / \mathrm{s}$, a sort of plateau which shows up clearly on the hydrogram (Fig. 2), and is roughly equivalent to what is turbined at Manantali. In this respect things have changed from the time when, in the late 1980s and throughout the 1990s, the dam could be closed for extended periods, resulting in an excessive buildup of salt in the estuary's water (e.g. salt content was measured at $35.9 \mathrm{~g} / \mathrm{l}$ at Saint-Louis in May 1992 when Diama was closed (Cecchi, 1992)) and in the distinct recession of the mangrove. Although it obviously varies over space and time, surface salinity measured in December 2004 and May 2005 did not seem excessive, despite low and similar discharges from Diama (respectively 100 and $165 \mathrm{~m}^{3} / \mathrm{s}$ ).

It must be pointed out, however, that these measurements were not made in the extreme downriver area of the estuary, particularly the section of the river between the new mouth and the old one, which is now filled in; this section is very near the ocean

and is turning into a lagoon with, most likely, a very high salt content due the lack of any "flushing" effect. The flow of seawater into this area appears to be potentially much more of a threat to certain agro-sylvo-pastoral activities and to fresh-water supplies. Indeed, the market-gardening economy of the Gandiolais district already seems to

HESSD

4, 4297-4323, 2007

Water management in the Senegal River Delta

M. Mietton et al.

Title Page

Abstract Introduction

Conclusions

Tables References Figures

14 $\rightarrow$

4

Back

Close

Full Screen / Esc

Printer-friendly Version

Interactive Discussion 
have been affected by these changes (Diallo, 2005).

The ubiquity of patches of fresh water overlying the saltwater table in the lower delta's dune ridges had enabled the Gandiolais, downriver from St-Louis, to become an economically dynamic zone. The freshwater table had already begun falling in the 1970s, 5 owing to drought, then to development works on the river and to the disappearance of natural flooding. This drop in water supply encouraged the planting of a new crop requiring less water, namely onions, instead of other traditional vegetables (Bonnardel, 1992). The thin layer of fresh water has seemed irreversibly threatened since the breach was opened. Exchanges between the river and the lateral water tables have - clearly been modified and the amplification of the tidal range has undoubtedly resulted in contamination of the thin surface layer. It is therefore essential for piezometric levels and water quality to be closely monitored.

Crop growing in the Gandiolais district appears to be more or less living on borrowed time, according to how far it is from the now passive section of the river and to the height of the ground it is on. In the most favourable cases, water from wells on the plots of land is the least salty $(1.8 \mathrm{~g} / \mathrm{l}$ at most for the series of measurements made in February 2006). On the other hand, salinity can reach $2.9 \mathrm{~g} / \mathrm{l}$ on plots located near the river or which are low-lying. Yields are apparently lower in these areas, and onion shoots show characteristic signs of withering. Certain plots even closer to the river have been completely abandoned in the last year or two, with well water having a salt content of $12.5 \mathrm{~g} / \mathrm{l})$.

\section{Conclusions}

In today's Senegal River Delta, environmental uncertainty is being felt in a number of ways: ecological, socio-economic and sanitary. The constraints have at least one point

in common: uncertain control of the quantity and quality of water resources (fresh, brackish, and sometimes waste water). They differ, however, between the three zones of the Senegalese middle delta, the Mauritanian middle delta, and the estuary with its

\section{HESSD}

4, 4297-4323, 2007

Water management in the Senegal River

Delta

M. Mietton et al.

Title Page

Abstract

Introduction

Conclusions

Tables

References

Figures

14

4

Back

Close

Full Screen / Esc

Printer-friendly Version

Interactive Discussion 
surrounding area.

On the left bank of the middle delta, Senegalese rice growers have to contend with serious problems, so that uncertainty is inherent to the whole production system (Leroy, 2006). In his report on sustainable development in the Senegalese part of the delta,

5 de Montgolfier (1996) foresaw at least three possible, non-exclusive scenarios: stagnation; the development of African farming concerns and/or of modern subsistence farming; neo-capitalism, international tourism. The "neo-capitalist" hypothesis is already on the way to becoming a reality, at least partly, especially with the development of foreign-owned companies (e.g. Grands Domaines du Sénégal) which are growing 10 vegetables with high added value such as beans and tomatoes in vast, drop-by-drop irrigated, greenhouses (already 200 ha in 2003) for export by air. As for tourism, it should benefit from the creation of a cross-border biosphere reserve (RBT-UNESCO), merging Djoudj and Diawling Parks, in Senegal and Mauritania respectively, thus forging closer links between the two countries.

15 In the Mauritanian part of the delta, there has not been so much upset. If traditional stakeholders are building up an effective harmony, then smoother, or at least less socially costly, socio-economic development than on the left bank seems a likely prospect.

Within the estuary, it is still too early for a proper assessment of the impact of the artificial opening of Barbary Spit. The remedy chosen to treat flood risks in SaintLouis may nevertheless prove to be worse than the original affliction, at least in the section downriver from Diama in the area near the former branch now transformed into a lagoon. The monitoring of ecological parameters and socio-economic indicators is urgently required, as is hydraulic modelling of the section of the river between Diama and the ocean.

Many of the uncertainties outlined here stem from impact studies which did not clearly show up all the difficulties likely to arise after such radical landscape transformation or whose purpose was not to devise real, concrete compensatory measures, i.e. ones with actual financing as immediate and substantial as that used to build the

HESSD

4, 4297-4323, 2007

Water management in the Senegal River

Delta

M. Mietton et al.

Title Page

Abstract

Conclusions

Tables

Figures

14

$\rightarrow 1$

4

Back

Close

Printer-friendly Version

Interactive Discussion

EGU 
dams themselves. To those who brings out that the benefits derived by a dam have to be reasonably assessed in the long run, one can easily answer that this period of adaptation and uncertainty is lived with difficulty by local stakeholders; it has to be anticipated and reduced as much as possible.

\section{References}

Albergel, J., Bader, J.-C, Lamagat, J.-P., and Séguis, L.: Crues et sécheresses sur un grand fleuve tropical de l'Ouest africain : application à la gestion de la crue du fleuve Sénégal, Sécheresse, 4(3), 143-152, 1984.

Bader, J. C., Lamagat, J. P., and Guiguen, N.: Gestion du barrage de Manantali sur le fleuve 10 Sénégal : analyse quantitative d'un conflit d'objectifs, Hydrolog. Sci. J., 48(4), 525-538, 2003.

Barusseau, J. P., Cyr Descamps, M. B., Salif Diop, E., Diouf, B., Kane, A., Saos, J.-L., and Soumaré, A.: Morphological and sedimentological changes in the Senegal River estuary after the constuction of the Diama dam, J. Afr. Earth Sci., 26(2), 317-326, 1998.

Blanchon, D.: Impacts environnementaux et enjeux territoriaux des transferts d'eau inter bassins en Afrique du Sud, Unpublished PhD thesis, Université de Paris X Nanterre, 624 pp., 2003.

Bonnardel, R.: Saint-Louis du Sénégal: mort ou renaissance ? Paris, L'Harmattan, 423 pp., 1992.

Bousso, T.: The estuary of the Senegal River: the impact of environmental changes and the Diama dam on resource status and fishery conditions. In Africa inland fisheries, aquaculture and the environment, edited by: Remane, K., Fishing News Books, Oxford, UK, 45-65, 1997.

Cecchi, P.: Phytoplancton et conditions de milieu dans l'estuaire du fleuve Sénégal : effets du barrage de Diama. Unpublished PhD thesis, Université de Montpellier II, Travaux et Documents de l' ORSTOM Microédités, 94, 437 pp., 1992.

Ceuppens, J. and Woperei, M. C. S.: Impact of non-drained irrigated rice cropping on soil salinization in the Senegal River Delta, Geoderma, 92(1-2), 15, 125-140, 1999.

Coyne and Bellier and Sogreah: Consignes générales d'exploitation et d'entretien du barrage
HESSD

4, 4297-4323, 2007

Water management in the Senegal River

Delta

M. Mietton et al.

Title Page

Abstract

Introduction

Conclusions

Tables

References

Figures

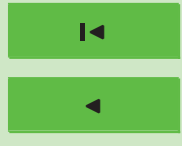

$\rightarrow$

Back

Close

Full Screen / Esc

Printer-friendly Version

Interactive Discussion 
De Montgolfier, J.: Interrogations sur le développement durable dans le delta du fleuve Sénégal, Compte-rendu de mission janvier 1996, Programme CNRS - PIR EVS SEAH "Transformations des hydrosystèmes en aval des grands barrages" Edited by: Mietton, M., Unpublished, 18 pp., 1996.

5 Diallo, M.: Etude de la baisse du niveau de la nappe dans les Niayes du Gandiolais, Mémoire de Maîtrise, Université G. Berger, U. F. R. Lettres et Sciences Humaines, section Géographie, 120 pp., 2005.

Duvail, S.: Scénarios hydrologiques et modèles de développement en aval d'un grand barrage, Les usages de l'eau et le partage des ressources dans le delta mauritanien du fleuve 10 Sénégal, PhD thesis in Geography, Université L. Pasteur, Strasbourg I, 305 pp., 2001.

Duvail, S. and Hamerlynck, O.: Mitigation of negative ecological and socio-economic impacts of the Diama dam on the Senegal River Delta wetland (Mauritania), using a model based decision support system, Hydrol. Earth Syst. Sc., 7(1), 133-146, 2003.

Duvail, S., Mietton, M., and Gourbesville, P.: Gestion de l'eau et interactions société-nature, Le cas du delta du Sénégal en rive mauritanienne.,Nature Sciences Sociétés, 9(2), 5-16, 2001.

Engelhard, P.: La vallée " revisitée " ou les "Enjeux de l'après-barrage" cinq ans plus tard, in: La vallée du fleuve Sénégal, Evaluations et perspectives d'une décennie d'aménagements, sous dir. Crousse, B., Mathieu, P., and Seck, S. M., Paris, Karthala, 45-79, 1991.

20 Hamerlynck, O., Duvail, S., Messaoud, B., and Benmergui, M.: The restoration of the Lower Delta of the Senegal River, Mauritania (1993-2004), Symposium on Coastal Ecosytems of West Africa, Brussels, Belgium, 15-16 February, 11 pp., 2005.

Humbert, J., Mietton, M., and Kane, A.: L'après-barrages dans le delta du Sénégal, Scénarios de remise en eau de la cuvette du N'Diael et impacts, Sécheresse, 6(2), 207-214, 1995.

Kane, A.: L'après-barrages dans la vallée du fleuve Sénégal: modifications hydrologiques, morphologiques, géochimiques, sédimentologiques, Conséquences sur le milieu et les aménagements hydro-agricoles, State doctoral thesis, Dakar, UCAD, 551 pp., 1997.

Kane, A., Niang Diop, I., Niang, A., and Dia, A. M.: Coastal impacts of water abstraction and impoundment in Africa, Cas du bassin du fleuve Sénégal, LOICZ/START AfriCat Foundation Project, Université C. A. Diop, 90 pp., 2003.

Laperrière, V. and Luchetta, J.: La dynamique du risque d'inondation à Saint-Louis au Sénégal, Master's dissertation, Université Joseph-Fourier, Institut de Géographie Alpine, Grenoble, 167 pp., 2003.

HESSD

4, 4297-4323, 2007

Water management in the Senegal River

Delta

M. Mietton et al.

Title Page

Abstract

Introduction

Conclusions

Tables

References

Figures

14

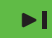

4

Back

Close

Full Screen / Esc

Printer-friendly Version

Interactive Discussion 
Leroy, M.: Gestion stratégique des écosystèmes du fleuve Sénégal, Actions et inactions publiques internationales, Etudes africaines, L'Harmattan, 623 pp., 2006.

Mahé, G. and Olivry, J. C.: Variations des précipitations et des écoulements en Afrique de l'Ouest et central de 1951 à 1989, Sécheresse, 6(1), 109-117, 1995.

5 Mietton, M., Humbert, J., and Richou, S.: Le projet de remise en eau du N'Diael (Sénégal), Pré-faisabilité hydraulique, bilan hydrologique et impacts, Consultants' report for the C.I.C. Université Louis-Pasteur Strasbourg, CEREG URA 95, 73 pp. plus annexes, 1991.

Pesneaud, F.: Artificialisation du milieu, introduction de techniques nouvelles et recomposition sociale: à propos de la riziculture du delta du Sénégal, Compte-rendu de mission janvier 1996. Programme CNRS - PIR EVS SEAH "Transformations des hydrosystèmes en aval des grands barrages" edited by: Mietton, M., Unpublished, 19 pp., 1996.

Philippe, C., Kane, A., Handschumacher, P., and Mietton, M.: Aménagements hydrauliques et gestion de l'environnement dans le delta du fleuve Sénégal, in: Pratiques de gestion de l'environnement dans les pays tropicaux, Dymset, CRET, Espaces tropicaux nr 15, 389-401, 1998.

Puech, C.: Persistance de la sécheresse au Sahel, Conséquences sur les normes hydrologiques et pluviométriques, C.I.E.H., série Hydrologie, Ouagadougou, 24 pp. plus annexes, 1983.

Theuerkorn, W. and Henning, R. K.: Energies renouvelables: Typha australis, menace ou richesse? Rapport du Comité permanent Inter-Etats de Lutte contre la Sécheresse dans le Sahel (CILSS), Cellule régionale de coordination du programme régional de promotion des énergies domestiques et alternatives au Sahel (PREDAS), Bundesministerium für wirtschaftliche Zusammenarbeit und Entwicklung, 28 pp., 2005.

UNEP/UCC-WATER/SGPRE: Towards an integrated management of the coastal zone and the Senegal river basin, Pilot program for the left bank of the Senegal river delta and its coastal zone, 88 pp., 2002.

Venema, H. D., Schiller, E. J., Adamowski, K., and Thizy, J.-M.: A Water Resources Planning Response to Climate Change in the Senegal River Basin. J. Environ. Manage., 49(1), 125155, 1997.

\section{HESSD}

4, 4297-4323, 2007

Water management in the Senegal River

Delta

M. Mietton et al.

Title Page

Abstract

Introduction

Conclusions

Tables

References

Figures

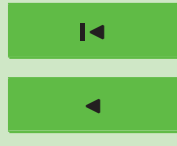

$\rightarrow 1$

Back

Close

Printer-friendly Version

Interactive Discussion 


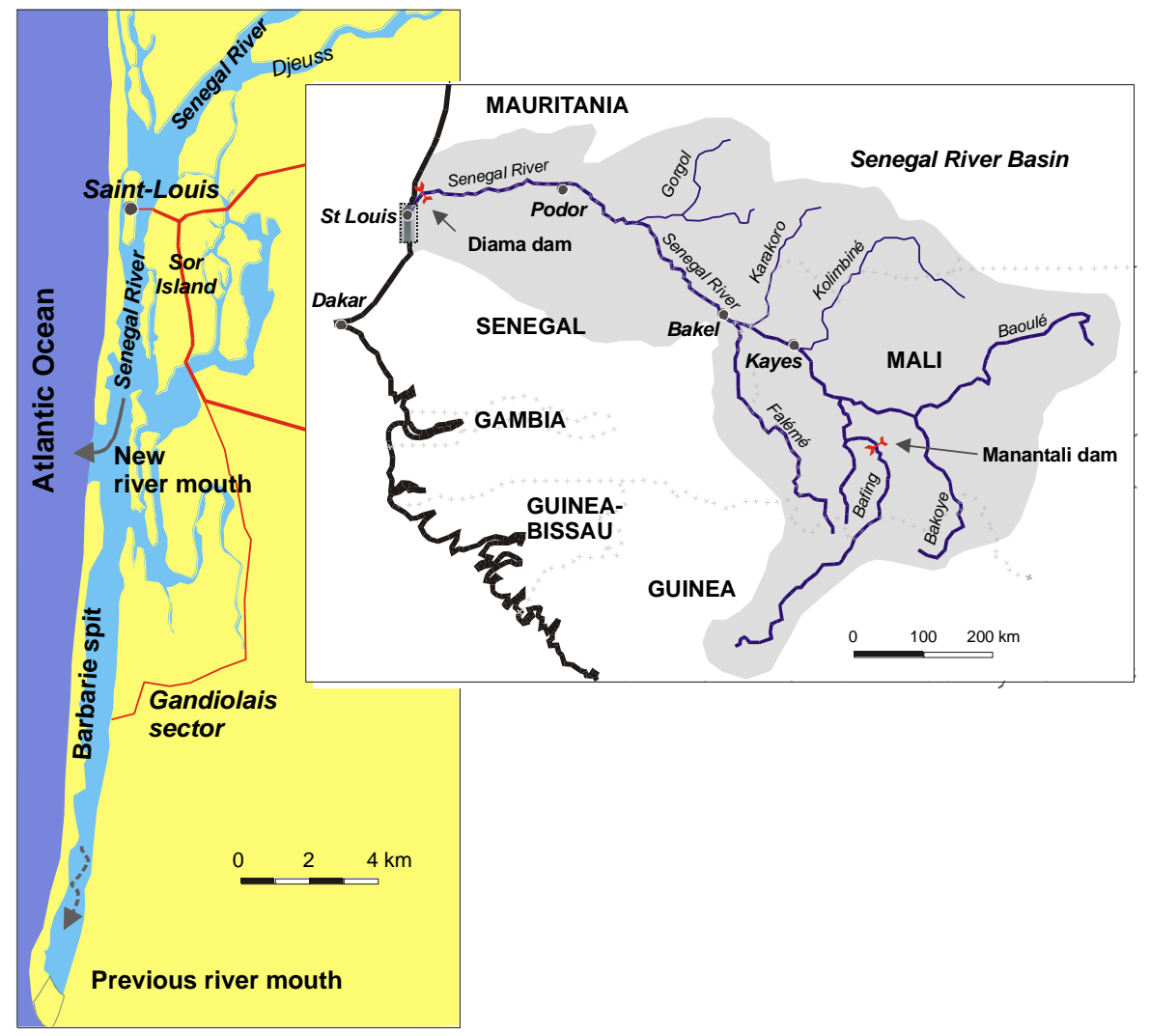

4, 4297-4323, 2007

Water management in the Senegal River Delta

M. Mietton et al.

Title Page

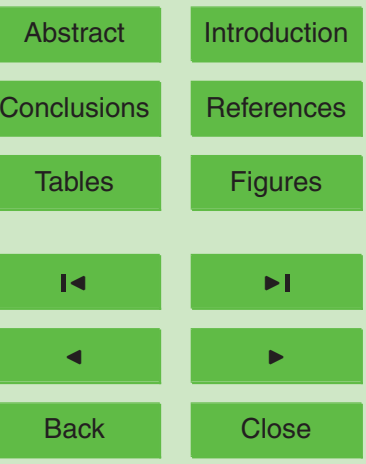

Full Screen / Esc

Printer-friendly Version

Fig. 1. Senegal River basin and its new mouth.

Interactive Discussion 


\section{HESSD}

4, 4297-4323, 2007

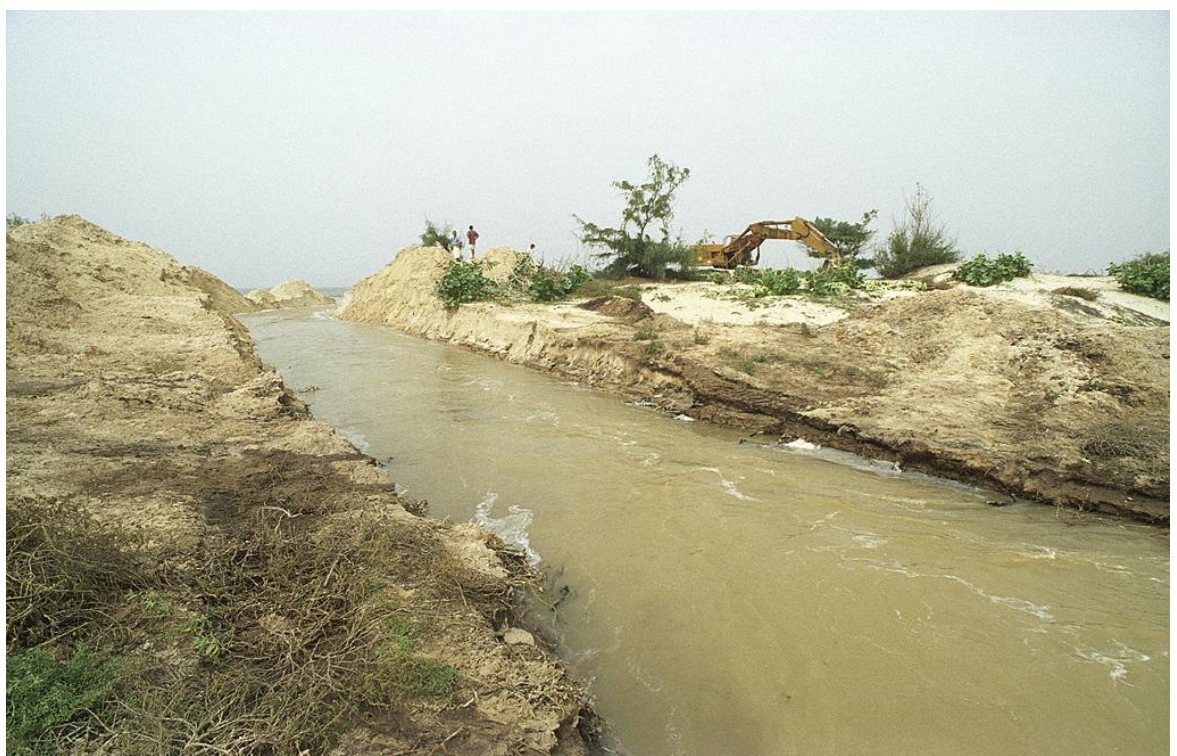

Water management in the Senegal River Delta

M. Mietton et al.

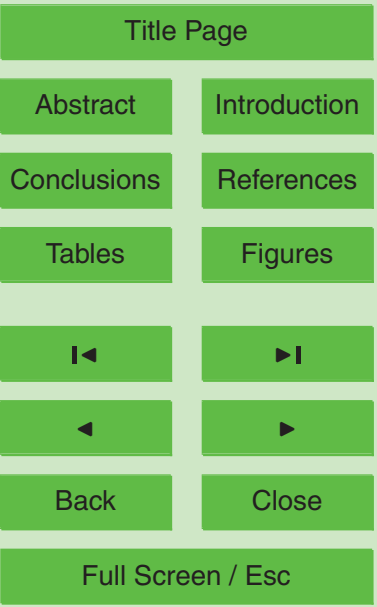
west. (Photo: M. Gerrer, handed over by N. Guiguen, IRD).

Printer-friendly Version

Interactive Discussion 


\section{HESSD}

4, 4297-4323, 2007

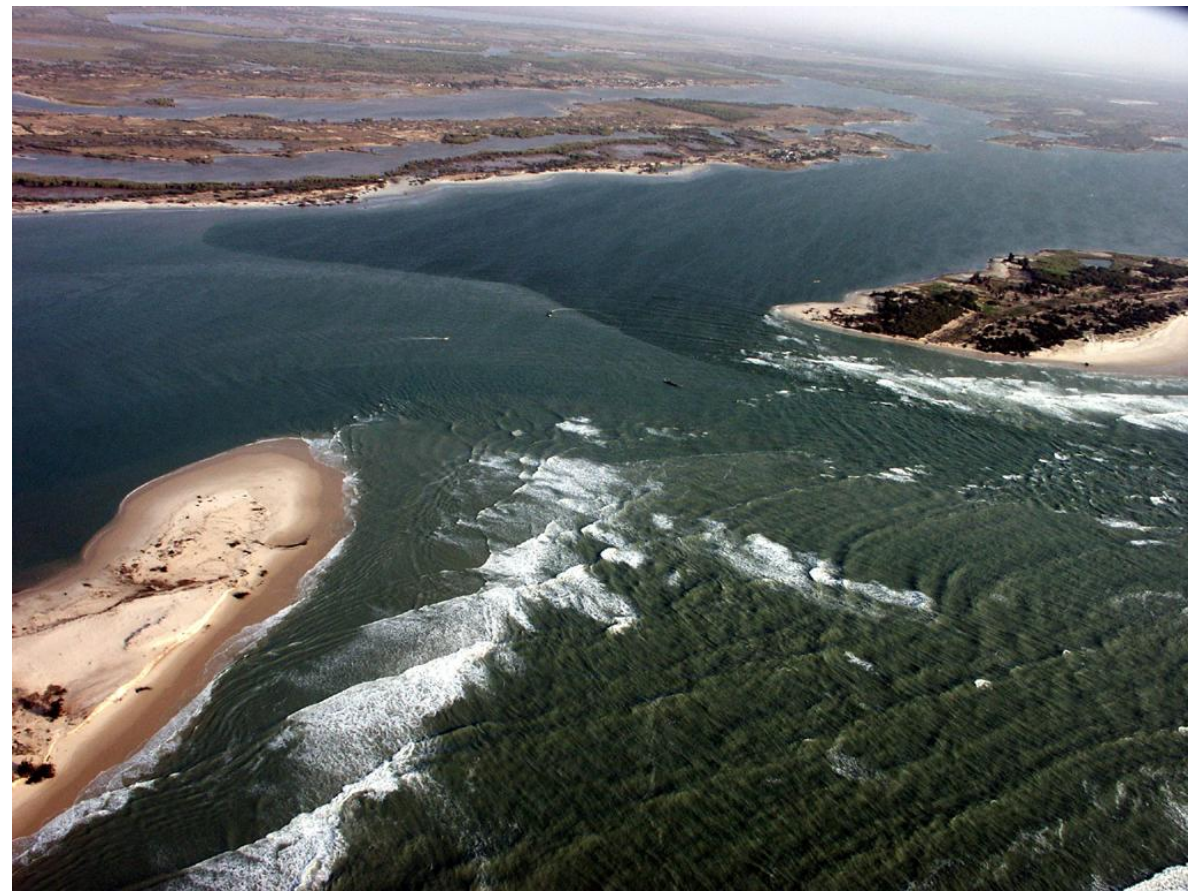

Water management in the Senegal River Delta

M. Mietton et al.

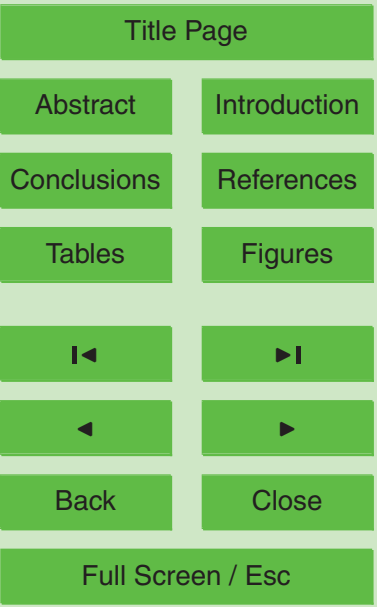

Fig. 3. Barbarie spit breach in 2005, looking southeast (Photo: M. Gerrer, handed over by N. Guiguen, IRD).

Printer-friendly Version

Interactive Discussion

EGU 


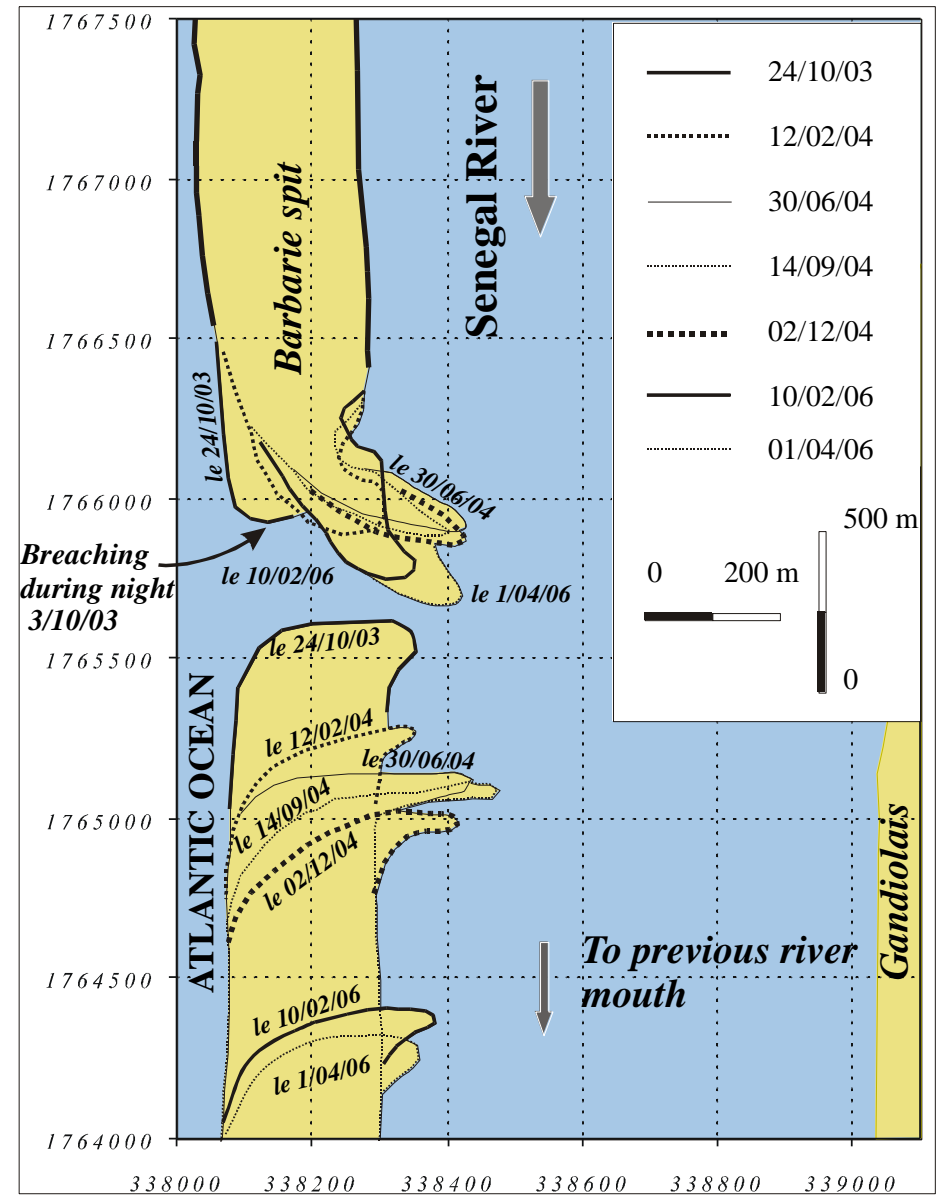

HESSD

4, 4297-4323, 2007

Water management in the Senegal River Delta

M. Mietton et al.

Title Page

Abstract

Introduction

Conclusions

References

Tables

Figures

I

$\rightarrow$ I

4

Back

Close

\section{Full Screen / Esc}

Printer-friendly Version

Interactive Discussion

EGU

Fig. 4. Time-space evolution of the new mouth between October 2003 and April 2006 (data from N. Guiguen and autors. 


\section{HESSD}

4, 4297-4323, 2007

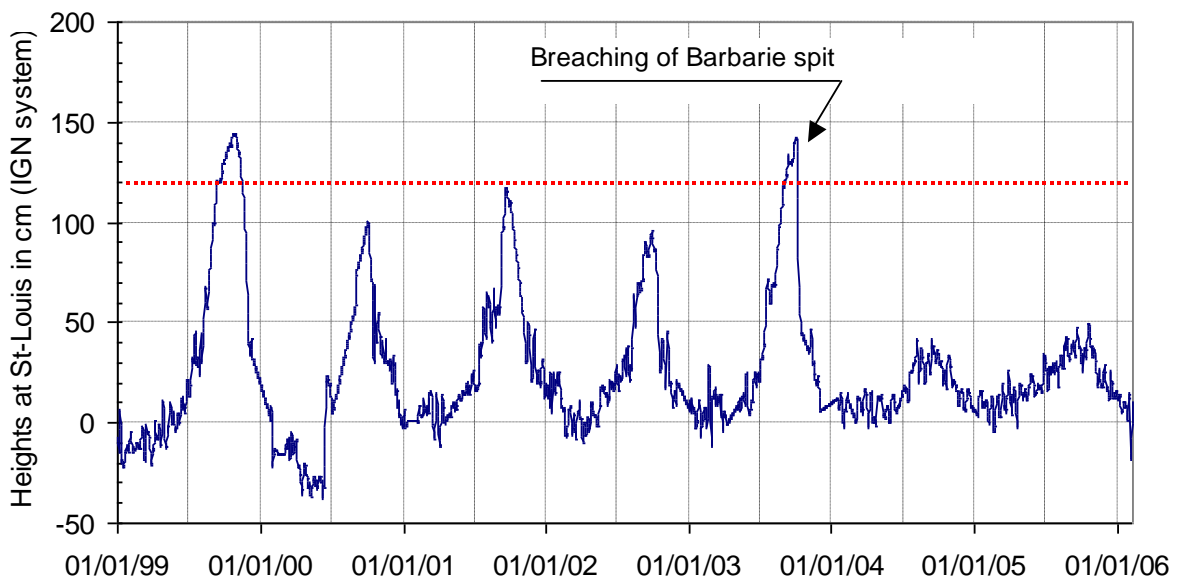

Water management in the Senegal River Delta

M. Mietton et al.

Title Page

Abstract

Introduction

Conclusions

References

Tables

Figures

I

\section{I}

4

Fig. 5. Limnimetric variations at St-Louis (1999-2006), data from OMVS-IRD database. Note end of annual flood and immediate effect of spit breaching. The horizontal red line shows flood threshold at St-Louis city.

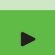

Close

Full Screen / Esc

Printer-friendly Version

Interactive Discussion 


\section{HESSD}

4, 4297-4323, 2007

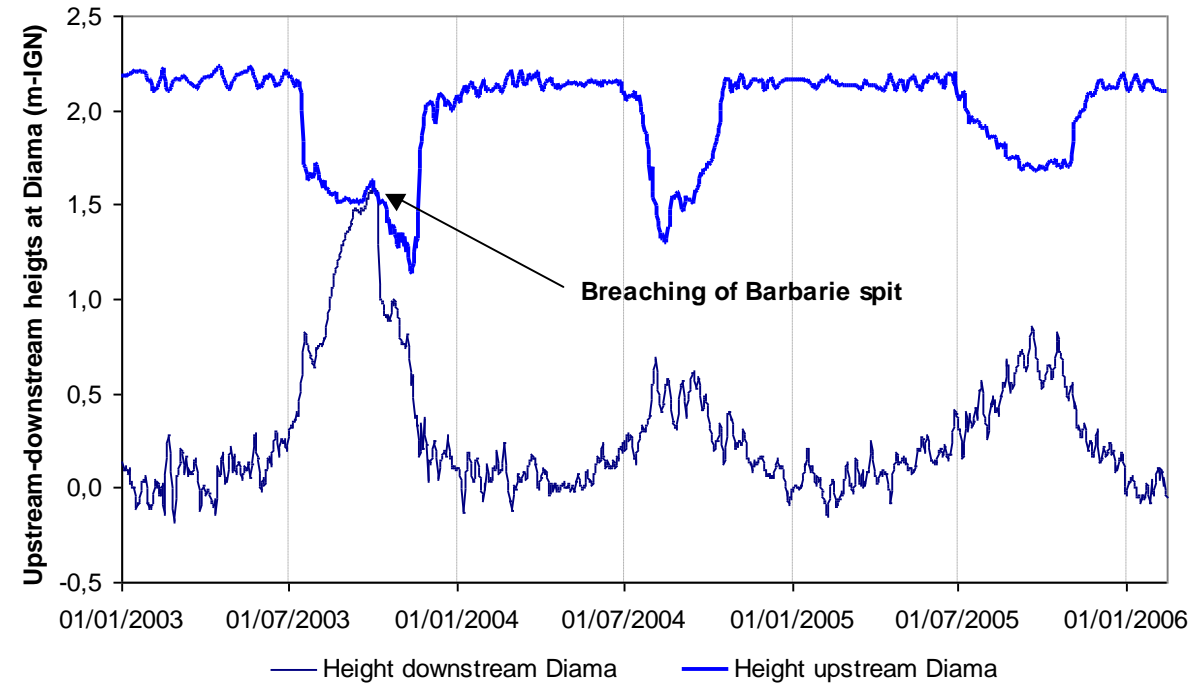

Fig. 6. Mean daily water heights at Diama Dam. Computed after aperiodic recordings downstream, at $12 \mathrm{~h}$ upstream (data from OMVS-IRD database).
Water management in the Senegal River Delta

M. Mietton et al.

Title Page
Abstract

Conclusions

Tables

14

4

Back

\section{Introduction}

References

Figures

$\rightarrow$

Close
Full Screen / Esc

Printer-friendly Version

Interactive Discussion 


\section{HESSD}

4, 4297-4323, 2007

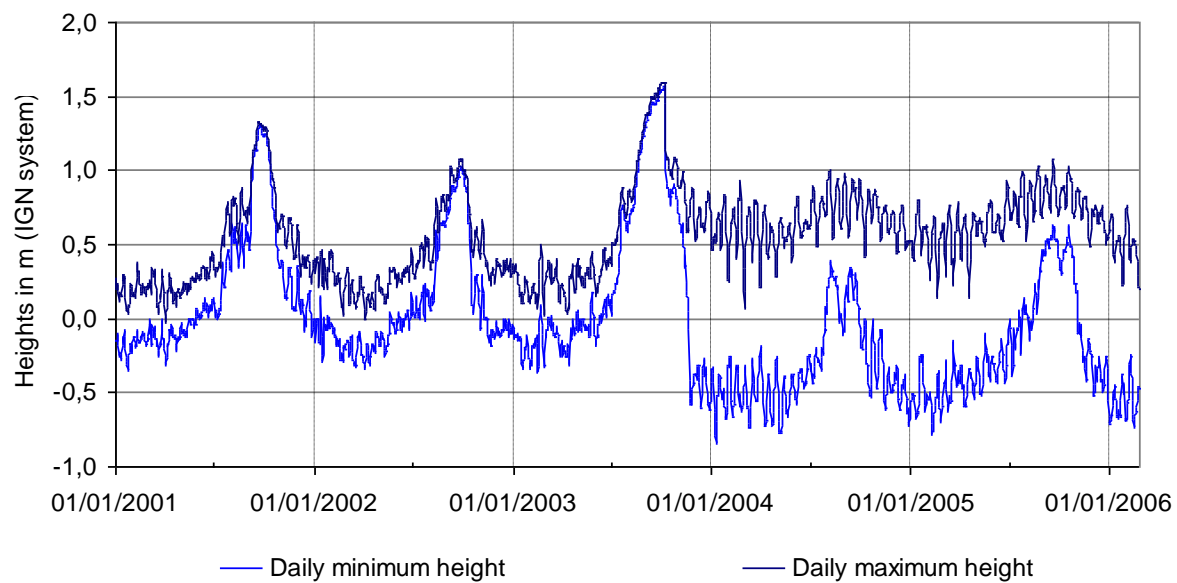

Water management in the Senegal River Delta

M. Mietton et al.

Title Page

Abstract

Introduction

Conclusions

References

Tables

Figures

14

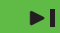

4

Back

Close

\section{Full Screen / Esc}

Printer-friendly Version

Interactive Discussion 